\title{
私の腸管病原性菌研究——腸炎ビブリオ・ 赤痢菌・大腸菌・コレラ菌
}

\author{
竹田美文
}

（名誉会員）

\section{I. はじめに}

1960 年, 大阪大学医学部を卒業した私は, 翌年大阪 大学大学院医学研究科に入学し, 大阪大学微生物病研究 所の藤野恒三郎先生の指導の下で腸管感染症の研究を始 めた。藤野先生は, 昭和 25 (1950) 年, 大阪府下泉南地 方で発生した “シラス食中毒事件” の際, 腸炎ビブリオ を食中毒原因菌として発見した。シラス食中毒事件は, 患者数 272 名中 20 名が死亡するという大食中毒事件で あった。しかし, 病原細菌はパストゥール, コッホの活 躍した 19 世紀後半にすべて発見し尽くされてしまって いる, という当時の学会の常識屯あって, 私が大学院学 生として研究を始めた当時は, 腸炎ビブリオ（当時病原 性好塩菌と呼ばれていた）を腸管病原性菌之認める研究 者は，学会の中で極めて少数だった。

\section{II. 腸炎ビブリオの研究}

大学院学生として最初に与えられたテーマは, 病原性 好塩菌の分類学的研究であった。藤野先生は発見した新 種菌を, 当時の分類学的基準に照らして Pasterella parahemolytica 之命名していたが, 分類学の進歩に伴っ て, Vibrio 属菌ではないかと考えられるようになってい た。当時, Vibrio 属菌であることを示す分類の基準の一 つにコレラレッド反応というのがあった。保存していた 菌株がコレラレッド反応陽性であることを報告した和文 論文が私の処女論文である。その後 1963 年, 国立予防 衛生研究所 (当時) の坂崎利一博士らが, 総括的な分類 学的研究をまとめて, 新種名 Vibrio parahaemolyticus を提案した。Bergy's Manual Determinative Bacteriology が Vibrio parahaemolyticus (Fujino, Okuno, Nakada, Aoyama, Fukai, Mukai, Ueho, 1951) Sakazaki, Iwanami, Fukumi, 1963 を初めて登載した のはその第 8 版, 1974 年のことであった。発見から 20 年近くが経っていた。

和名 “腸炎ビブリオ” は, 1963 年 6 月, 当時大阪市内 堂島にあった阪大微研講堂で行われた厚生科学研究費班 会議の席上で, 国立予防衛生研究所の福見秀雄先生が提 案した。

腸炎ビブリオの耐熱性溶血毒の研究を始めたのは, 1970 年代の前半であった。毒素の精製, 生化学的性状 の解明が順調に進み, さらに, 本田武司博士 (現 阪大名
誉教授）が，心臓毒性を明らかにした。マウス胎児心臟 の初代培養細胞が顕微鏡下で規則正しく拍動するのに感 動し, その拍動が微量の精製耐熱性溶血毒の添加で停止 するのに驚愕したことだった。シラス中毒事件の際の死 者数は異常に多いとしても, 現在であ, 腸炎ビブリオ食 中毒による死者は少なからず存在するはずである。その 検証が難しいために, 統計として記録されないだけであ ると私は考えている。これらの死亡の原因が耐熱性溶血 毒の心臟毒性によると考えられるが，それを証明するこ とは，現在の科学技術では難しいと思う。

\section{III. 赤痢菌の研究}

腸炎ビブリオの耐熱性溶血毒による死亡の可能性を確 信したころ，ヒトの死亡原因となりうる細菌毒素とし て, 志賀赤痢菌の産生する志賀毒素の研究を始めた。志 賀毒素については, 1950 年代に多くの論文が報告され ていたが，その後は研究課題としてあまり取り上げられ ていなかった。

精製は困難を極めたが, 岡本 敬の介博士 (現 岡山大 学大学院医歯薬学総合研究科教授), 湯通堂 隆博士 (現 塩野義製薬）らによって精製毒素を得ることができ，毒 素の生化学的, 生物学的諸性状を明らかにした。この研 究の成果で何よりも重要なことは，この精製毒素とその 抗体が, 後に腸管出血性大腸菌の研究に大きな役割を演 じることになったことで, 研究の展開の妙味を十分に味 わった。

\section{IV. 毒素原性大腸菌の研究}

1970 年代後半から, 旅行者下痢症の原因菌として毒 素原性大腸菌が非常に重要であるという論文が, 次々に 報告されるようになった。当時伊丹空港内にあった厚生 省大阪空港検度所の阿部久夫技官 (故人) のグループと, わが国の海外旅行者の現状について調べた。その結果, 東南アジアなどの熱帯・亜熱帯の開発途上国から帰国す る旅行者下痢症患者の $30 \%$ は毒素原性大腸菌によるこ とがわかった。

毒素原性大腸菌の下痢原因毒素として, 当時すでに易 熱性エンテロトキシン (LT) と耐熱性エンテロトキシン (ST) の存在がわかっていた。しかし, 精製毒素の性状は まだほとんどわかっていなかったので，まずLTの精製 
から研究を始めた。外国の研究グループとの厳しい競争 の中で, LTにはヒト由来菌の LTh とブ夕由来菌の LTpの 2 種類があることを, 蛋白質レベル明らかにす ることができた。しかしこの研究は, 当時急速な勢いで 発達していた遺伝子解析による成果に先を越された。

一方 ST の研究は，精製には手間取ったものの，大阪 大学蛋白質研究所の下西康嗣博士 (現 大阪大学名誉教 授）の研究グループとの共同研究で, 世界に先駆ける成 果を次々に発表した。まずSTにもヒト由来菌の STh とブタ由来菌の STpの 2 種類の分子があること, 両者 とも 19〜20 種類のアミノ酸からなるペプチドであるこ とを明らかにした。さらに, 生物活性のある STh と STp の化学合成に成功し, 同時に化学合成の技術を駆使 して, 活性の最小単位を同定することができた。この研 究には, 58 歳の若さで逝った竹田多恵が活躍した。

\section{V. 腸管出血性大腸菌の研究}

1983 年 2 月, 東京大学医科学研究所細菌感染研究部 の教授に就任したのを機会に, 腸管出血性大腸菌の研究 を始めた。その前年, 米国のワシントン州を中心に初め ての E. coli O157 による食中毒が報告され, New England J. Med. 誌に掲載された CDC の研究グループの論 文が大きい反響を呼んでいたこと，さらに，同菌が産生 する Vero 毒素が Shigella dysenteriae 1 の産生する志 賀毒素と免疫学的に共通していることを O’Brien らが 報告していたこと, カナダの Karmali らが散発例から E. coli $\mathrm{O} 157$ を分離していることなどが, 新しい魅力あ る研究テーマとして取り上げる理由であった。

大阪府立公衆衛生研究所の塚本定三博士 (当時) に調 整してもらったE. coli $\mathrm{O} 157: \mathrm{H} 7$ の診断用抗血清 (O157 と H7 それぞれの抗血清) を, 東大医科研病院臨 床検査室 (当時) の安達房代さんの助力を得て, 在京の 臨床検査技師に広く配布し, E. coli O 157 : H7 (以下 O157）の患者からの分離を依頼した。わが国にも腸管出 血性大腸菌感染症の患者が存在するに違いないと考えて のことだった。ほどなく, 某感染症病院で患者から O157 が分離された。菌株名を J2 と付したこの菌株は, 以下に述べるように, たいへん貴重な研究材料となっ た。

前述した赤痢菌の研究の際に調整した精製志賀毒素の 抗体をマーカーにして, カナダの H. Lior 博士に分与し ていただいた菌株から Vero 毒素を精製し, 生化学的, 生物学的諸性状を明らかにした。その課程で, 上記 J2 株の Vero 細胞に対する細胞毒性が志賀毒素の抗体で中 和されないことを発見した。VT2 の発見であった。現象 の発見で短報を発表すべきであったが，精製にこだわっ て発表が遅れ, 英国と米国の研究グループに, VT2 の存 在を先に報告されてしまった。

志賀毒素の作用機作は, 千葉大学薬学部の五十嵐一衛 博士 (現 千葉大学名誉教授), 山梨医科大学の遠藤弥重
太博士 (現 愛媛大学名誉教授) との共同研究で明らかに した。すなわち, Vero 毒素は蛋白合成阻害毒素で, その 分子機構はリボソームの $60 \mathrm{~S}$ サブュニットを構成する 28S リボソーマル RNA の 5' 末端から 4,324 番目のア デノシンのグリコシド結合を加水分解する RNA-Nglycosidase 活性があり, その結果, リボソームへのア ミノアシル tRNA の結合を阻害し, ひいては蛋白質合成 を阻害することを証明した。

腸管出血性大腸菌感染症は, その産生するVero 毒素 により, 出血性大腸炎, HUS, 脳症を起こし, 患者を死 に至らしめる重要な腸管感染症である。米国では，年間 の患者数が約 21,000 名で, そのうち死者が 250 名に達 するという推計が報告されている。すなわち，患者の約 12\% が死亡するという推計になる。わが国では，2001 年の感染症法の施行以来, 腸管出血性大腸菌感染症患者 数は正確に把握されていて，毎年 3,000～4,000 名の患 者が発生している。むし上述の米国の推計を当てはめる と, 年間 30〜50 名の死者が出ていることになる。しか し, 実際にはこのような多数の死者は感染症統計に登載 されていない。それはおそらく以下のような理由であろ うと思われる。

すなわち, 腸管出血性大腸菌感染症の場合, HUS を発 症するのは出血性大腸炎の症状がなくなって 1 2 週間 後であり, さらにその後, 脳症を発症するのはしばらく 経ってからである。死亡の原因が HUS ないしは脳症で あることを考えると, 死亡の時点で便中に腸管出血性大 腸菌は存在しない。したがって, 散発例では, 腸管出血 性大腸菌感染症による死亡と診断されない。患者血清中 の志賀毒素または O157 などの LPS 抗原に対する抗体 での診断が行われない限り, 腸管出血性大腸菌感染症の 続発症による死亡という診断が難しいこととなる。

\section{VI. コレラ菌の研究}

コレラ菌の研究を始めたのは 1970 年代後半である。 コレラ毒素の研究で有名な Texas 大学医学部 (当時)の R. A. Finkelstein 博士と日米医学研究会コレラ部会の 米側委員長（当時）の J. Craig 博士が，それぞれサバ ティカルで, 当時私が助教授を務めていた大阪大学微生 物病研究所の三輪谷俊夫教授の研究室で 1 年近く滞在 したことと，当時私が務めていたWHOの Diarrheal Diseases Control Program の運営委員会でインド国立 コレラおよび腸管感染症研究所 (National Institute of Cholera and Enteric Diseases, NICED) 所長の S. C. Pal 博士と知り合ったことが大きなきっかけであった。

Pal 博士の招待で, 初めてコルカタの NICED を訪ね たのは1979年であった。それ以前にもバングラデシュ の国際下痢疾患研究センター (International Centre for Diarrhoeal Disease Research, Bangladesh; ICDDR, B) の理事会に何度か出席していたので，開発途上国を訪れ るのは初めてではなかった。しかし、コルカタと NICED 
とは私に強烈なインパクトを与えた。コレラの研究に取 り組むことを強く決意したのはこのときだった。

1982 年秋, NICED で G. B. Nair 博士と初めて会っ た。Nair 博士は, インド南部の大学で環境微生物学を専 攻して博士の学位を取得し, NICED に勤務し始めたば かりであった。それ以来今日まで，途絶えることなく共 同研究を続け，共著論文が 100 編を超す。なかでむ 1993 年の新型コレラ菌の発見は, 共同研究のハイライ トである。

1992 年 10 月, インド南部の港湾都市マドラス（現 チェンナイ）で，non-O1 コレラ菌によるコレラの大流 行が発生した。従来コレラの流行は, O1 コレラ菌に限 定されていて，たとえコレラ毒素産生菌であってあ, non-O1 菌による大流行は起こらないと考えられてい た。当時コレラ菌の血清型別で世界でただ一人の専門家 であった国立予防衛生研究所 (現 国立感染症研究所) の 島田俊夫博士に, 分離菌の血清型別を打願いした。その 結果, 島田博士が従来報告していた 138 種類のどの血清 型にも当てはまらないことがわかった。新しい血清型 (O139) のコレラ菌の発見である。

同じ頃，バングラデシュの ICDDR, B の研究者たち あ, バングラデシュの南部，ベンガル湾沿いのコレラ大 流行が non-O1 コレラ菌によることを発見した。島田博 士に血清型を依頼したところ，バングラデシュの菌株の 血清型もチェンナイでの分離菌と同一であることがわ かった。1993 年 3 月 13 日号の Lancet誌に, 私たちと ICDDR, B の新型コレラ菌 O139 発見論文が相前後して 掲載されている。

O139 コレラ菌は，またたく間にインド全国に広がっ
た。タイなどの近隣諸国へも拡大し，一時は第 8 次世界 大流行が起こることが心配されたが, その後, 影を潜め, 現在では時折インド亜大陸で分離されるにとどまってい る。

\section{VII. 岡山大学インド感染症共同研究センター}

2001 年 3 月に国立感染症研究所を最後に 36 年間務 めた公務員生活から退いていたが，2007 年 6 月，文部 科学省の新興・再興感染症研究拠点形成プログラムに よって, NICED 内に創設された岡山大学インド感染症 共同研究センター（インド拠点）に務めることになった。 久し振りの現場復帰で, 研究の勘を取り戻すのにしばら くかかったが，今では，インド拠点に駐在している岡山 大学の二人の若い研究者とと屯に, NICED の優秀な研 究者と, 楽しくコレラ菌の研究を展開している。

\section{VIII. おわりに}

恩師藤野恒三郎先生は, 私が腸炎ビブリオの研究をし ていた当時, 私どあに,「腸炎ビブリオの学問がいくら進 歩しても, 腸炎ビブリオ食中毒をゼロにしなければ困 る。この中毒を絶滅することこそ学者としての使命であ る」と繰り返し語られた。現在の言葉に置き換えると, translational research が重要であると説かれて扔られ たことになる。今，コルカ夕に駐在して，コレラで死ん でいく乳幼児を目にするにつけ，自分に残された年月の 間に，コレラによる死者を一人であ減らすことにつなが る研究成果を上げたいという思いに駆られる日々であ る。 